\title{
Neofunkcjonalny paradygmat elitystyczny - możliwości i warunki pogodzenia elity i demokracji
}

\section{The So-Called Neofunctional Elitist Paradigma as the Example of}

\section{Convergence between Elite and Democracy}

\begin{abstract}
The so-called neofunctional elitist paradigm forms the newest (although have been developed since the middle of 1970s) version of theory of elite. Nevertheless, the theory of elite originated in the end of $19^{\text {th }}$ century in sharp conflict with the democratic political system. The Italian "founding fathers" of the theory of elite (mainly Gaetano Mosca and Vilfredo Pareto) opposed some ideas of introducing the universal suffrage and moreover used the deep dissatisfaction connected with the process of unification of Italy (the process of Risorgimento). Already in 1928 Polish scholar Czesław Znamierowski presented some conditions of convergence between the necessity of elite and the existence of democratic political system.

In the view of some chief proponents of the so-called neofunctional elitist paradigm (mainly John Higley) some features of the elite forms an important criterion in the classification of democratic political systems. Even nowadays the most popular on the world scene are the divided elites. In such the situation the most important elite groups that function in the given society cannot get to cooperation or compromise even in the basic political questions. Undoubtedly, much better situation is the possibility of cooperation between elites (or at least between the most important elites). Such the cooperation can be based on the common ideology (the so-called ideological unified elites), like in the totalitarian political system. On the other hand, the best situation can be achieved when such the cooperation between elites is based on some values of democratic order (like in consensually unified elites). Already 30 years ago in Poland during the Round Table negotiations such the compromise had been achieved - in process of the so-called elite settlements.
\end{abstract}

Keywords: neofunctional elitist paradigm, divided elites, elite settlements, ideological unified elites, consensually unified elites 


\section{Uwagi wstępne}

Neofunkcjonalny paradygmat elitystyczny, jako najnowsza wersja teorii elity (choć rozwijana już od 40 lat), od dłuższego czasu znajduje się w kręgu moich zainteresowań badawczych (Żyromski 2006; 2008; 2009; 2016). Przygotowując obecnie książkę poświęconą tej koncepcji teoretycznej, korzystam z okazji do „zebrania myśli” i jednocześnie zainteresowania teoretyków polityki wskazaną $\mathrm{w}$ tytule szkicu teorią. Autorzy i propagatorzy neofunkcjonalnego paradygmatu elitystycznego (a zwłaszcza John Higley) stosują wymiennie pojęcie paradygmatu i teorii, uważając przy tym (niewątpliwie nazbyt skromnie), że ich koncepcja ciągle jeszcze nie zasługuje na miano teorii.

W swoim czasie poświęciłem wiele uwagi (i kilkaset stron druku) na przedstawienie ponadstuletniej ewolucji teorii elity (Żyromski, 2007). Dlatego też teraz chciałbym zwrócić uwagę tylko na najważniejsze trendy w jej rozwoju. Niewątpliwie nieprzypadkowo dwóch z „ojców założycieli” (Żyromski, 2012) teorii elity urodziło się we Włoszech (Gaetano Mosca i Vilfredo Pareto), a trzeci - Robert Michels (Miński, 2016) - przyjął pod koniec życia włoskie obywatelstwo (i nawet zmienił imię na Roberto). Po upadku Cesarstwa Rzymskiego na zachodzie (choć rok 476 ma tu głównie charakter symboliczny) Italia przez prawie 1400 lat była praktycznie podzielona i rozbita na wiele królestw, księstw czy nawet republik miejskich (jak Wenecja). Trudno się więc dziwić, że proces zjednoczeniowy (tzw. Risorgimento) spotkał się początkowo z bardzo pozytywnymi reakcjami, co można oglądać na licznych zdjęciach w specjalnym muzeum umieszczonym wewnątrz ogromnego pomnika ojczyzny (Altare della Patria) przy Piazza Venezia w centrum Rzymu. Szybko się jednak okazało, że „łatwiej było stworzyć Włochy niż Włochów" - odnosząc się do znanego i w dużej mierze aktualnego do dzisiaj powiedzenia. To przecież w ubiegłorocznych (2018 r.) wyborach parlamentarnych najlepszy wynik osiągnął populistyczny Ruch Pięciu Gwiazd, a wysokie notowania Ligi (jeszcze niedawno znanej jako Liga Północna) wskazują na ciągle aktualne pomysły separatystyczne (tzw. Padania, czyli tereny na północ od rzeki Pad). Stworzenie pod koniec XIX wieku teorii elity było reakcją na trudności procesu zjednoczeniowego, a także (a może raczej przede wszystkim) wyrażało obawy przed możliwymi skutkami procesu rozszerzania prawa wyborczego we Włoszech.

Jednocześnie pod koniec XIX wieku rozpoczął się proces tworzenia partii masowych w Europie Zachodniej. Korzystając z prawa do strajków, jeszcze w latach 70. XIX wieku zaczęły tworzyć się masowe związki zawodowe (zjednoczone Niemcy, Francja, Wielka Brytania), a na ich bazie powstawały równie masowe partie polityczne. Oczywiście proces dochodzenia do demokracji, chociażby poprzez stopniowe obniżanie cenzusu majątkowego jak w Wielkiej Brytanii (tzw. 
Reform Bills), był dość powolny (Żyromski, 1998), ale procesy demokratyzacji były już (a w wielu częściach naszego globu ciągle jeszcze są) raczej niemożliwe do zatrzymania. Mamy więc z jednej strony, oczywiście ujmując to w uproszczeniu, elitaryzm (wskazujący na dominującą pozycję elity w społeczeństwie), a $z$ drugiej tendencje demokratyczne (posuwające się czasami aż do populizmu), wskazujące na naczelną pozycję suwerena - czyli większości społeczeństwa. Czy i jak można pogodzić ze sobą te dwie tendencje?

Mniej więcej pół wieku przed zainicjowaniem koncepcji neofunkcjonalnego paradygmatu elitystycznego Czesław Znamierowski, późniejszy profesor prawa poznańskiego uniwersytetu, opublikował niewielką objętościowo książkę, ale o bardzo znaczącym tytule Elita $i$ demokracja (1928). Już sam czas jej wydania był dość znaczący, dwa lata wcześniej dokonano bowiem w Polsce przewrotu majowego, który nie tylko na bardzo długo podzielił polskie społeczeństwo, ale przyniósł także kilkaset ofiar śmiertelnych. $\mathrm{W}$ dużej mierze więc zawarte $\mathrm{w}$ książeczce uwagi miały (oczywiście bezskutecznie) skłonić rządzący obóz pomajowy w Polsce (tzw. rządy pułkowników) do prowadzenia polityki bardziej zgodnej $\mathrm{z}$ oczekiwaniami społecznymi. Znamierowski, uznając (podobnie jak wszyscy elityści) uniwersalność występowania elity, a jednocześnie wskazując na pozytywy systemu demokracji przedstawicielskiej, określił dwa warunki, które musiałaby spełnić elita, aby być $\mathrm{w}$ zgodzie $\mathrm{z}$ demokracją. Po pierwsze, elita nie powinna tworzyć zamkniętej kasty społecznej, tylko przyjmować do swego grona najlepsze osoby, wywodzące się z niższych warstw społecznych. Po drugie, elita powinna opierać się na osobach najlepszych (tzw. elita walorów), czyli ludziach najlepiej wykształconych i przygotowanych do piastowania najwyższych stanowisk w państwie, a ponadto dbających nie tylko o własne interesy, ale i o potrzeby szerszych warstw społecznych. Nawet pobieżna obserwacja zarówno ówczesnej, jak i współczesnej sceny politycznej - nie tylko polskiej zresztą - pokazuje, jak bardzo nierealne były to założenia. Niemniej samo wskazanie, już 90 lat temu, na możliwość pogodzenia elity i demokracji niewątpliwie warte jest odnotowania i przypomnienia. Autorzy neofunkcjonalnego paradygmatu elitystycznego poszli zresztą jeszcze dalej w swych rozważaniach (o czym poniżej). Dla nich bowiem pogodzenie elity i demokracji nie tylko jest możliwe, lecz stanowi również jedno z kryteriów klasyfikacji systemów demokratycznych.

\section{Uzasadnienie występowania elity i kwestie definicyjne}

Podobnie jak wszyscy inni elityści, także autorzy czy propagatorzy neofunkcjonalnego paradygmatu elitystycznego powinni opowiadać się za uniwersalnym występowaniem elity w społeczeństwie. W przypadku tej koncepcji uniwersal- 
ność jest jednak ograniczona czasowo. Według badaczy paradygmat elitystyczny powinien zostać ograniczony jedynie do społeczeństw industrialnych i postindustrialnych, ale za to z uwzględnieniem zarówno współczesnej cywilizacji zachodniej, jak i systemów totalitarnych czy autorytarnych. Przykładowo, zdaniem autorów neofunkcjonalnego paradygmatu elitystycznego, w małych społecznościach (np. kantony Szwajcarii w XVIII-XIX wieku) trudno byłoby się dopatrzyć jakiejkolwiek elity. Bowiem „[...] to nie sam fakt życia społecznego tworzy elity. Elity raczej pojawiają się wtedy, kiedy poziom organizacji społecznej dochodzi do punktu, w którym minimalny wspólny interes [poszczególnych] osób musi zostać uzupełniony przez autorytatywne decyzje - w celu utrzymania zbiorowych wysiłków. Tak więc to złożone organizacje, a nie samo społeczeństwo stanowi podstawę elity" (Higley, Deacon, Smart, 1979, s. 2). Z drugiej strony trudno byłoby jednak wykazać brak elity w tak dużym, złożonym i zorganizowanym organizmie społeczno-politycznym jak Cesarstwo Rzymskie (Żyromski, 1995). Dlatego też, jak słusznie zauważył Jacek Wasilewski, „koncepcja Fielda i Higleya jest w oczywisty sposób koncepcją o ograniczonym zasięgu. A priori wyklucza z obszaru swoich zainteresowań społeczeństwa preindustrialne" (Wasilewski, 1990, s. 41). Zdaniem twórców omawianego paradygmatu w takim przypadku mielibyśmy wprawdzie do czynienia $\mathrm{z}$ występowaniem klasy panującej, ale nie z funkcjonowaniem elity. Już jednak Gaetano Mosca, twórca teorii elity, stosował zamiennie terminy "klasa panująca” (classe dirigente) i „klasa polityczna” (classe politica) - jak nazywał samą elitę (Żyromski, 1996). „Elity wywodzą się z fundamentalnego i uniwersalnego faktu życia społecznego, a mianowicie $\mathrm{z}$ braku mocnego wspólnego interesu w jakiejkolwiek dużej zbiorowości. [...] W dużych zbiorowościach wspólny interes jest zupełnie minimalny i musi zostać uzupełniony przez decyzje autorytatywne” (Higley, 2010, s. 162). Tak więc, podobnie jak w opinii twórców teorii elity (a zwłaszcza Roberta Michelsa), konieczność występowania elity wiąże się szczególnie z wymogami organizacyjnymi systemu społeczno-politycznego danego państwa. „Uznanie tych prozaicznych faktów zorganizowania życia społecznego nadaje elitom znaczenie w teorii społecznej i politycznej. [...] organizacja wykraczająca poza pewien minimalny poziom i skomplikowanie koniecznie powoduje powstanie elit" (Higley, Field, Grøholt, 1976, s. 16).

Charakterystyczne, że początkowo autorzy analizowanej koncepcji bynajmniej nie unikali określenia „teoria”, pisząc, iż „teoria, którą przedstawiamy w tej książce, jest racjonalistyczna. Jest to teoria odpowiednich ról w polityce elit, a więc szczególnie wpływowych osób, oraz w polityce nie-elit, czyli szerszych populacji. Jest to teoria ogólna, mająca $\mathrm{w}$ zamierzeniu zmierzyć się z polityką we wszystkich typach ludzkich społeczeństw, chociaż nacisk został położony na doświadczenie współczesnej cywilizacji zachodniej” (Higley, Field, Grøholt, 1976, 
s. 10). Dopiero w kolejnych publikacjach pojawił się termin "paradygmat”, co tłumaczono potrzebą dalszego doskonalenia i uściślenia pojęciowego. Perspektywę teoretyczną twórców analizowanego paradygmatu określa jednak zwłaszcza umieszczenie go w ramach neofunkcjonalizmu (czy wręcz szerzej - myśli funkcjonalnej). Może dlatego wspomnianych autorów mniej interesują kwestie rekrutacji nowych członków do elity czy struktury elity, a zdecydowanie bardziej zajmują się rolą elit w społeczeństwie i państwie. „Punktem wyjścia paradygmatu Fielda i Higleya jest typowo funkcjonalistyczne pytanie o warunki stabilności systemu społecznego, a więc przede wszystkim o warunki stabilności politycznej" (Wasilewski, 1990, s. 27). I to właśnie rola elity czy funkcje pełnione przez elitę (elity) w ramach całego systemu społecznego wskazują jednocześnie na jej znaczenie - znaczenie zarówno teoretyczne, jak i praktyczne (empiryczne). „Zbiorowości o pewnej skali i złożoności wymagają decyzji osób, które zajmują w nich pozycje strategiczne. $Z$ uwagi na fakt, iż takie zbiorowości stanowią koncentrację władzy w ramach szerszego społeczeństwa, to ci decydenci mają nieproporcjonalnie dużą władzę i wpływ społeczny oraz prawie zawsze cieszą się nieproporcjonalnie dużymi przywilejami i ochroną. Jeśli nazwiemy je elitami, to możemy powiedzieć, iż duże i złożone społeczności z konieczności tworzą elity" (Higley, 2010, s. 163). Jednocześnie autorzy omawianego paradygmatu starają się (a przynajmniej deklarują) wyjść poza teorię funkcjonalną - podobnie zresztą jak starają się odróżnić od innych teorii stratyfikacji społecznej. „Podkreślając, że istotne wybory w polityce są podejmowane przez elity, ten paradygmat wyznacza elitom o wiele bardziej centralną pozycję w procesach politycznych i społecznych, niż uznają paradygmaty marksistowski, demokratyczny czy funkcjonalny" (Higley, Deacon, Smart, 1979, s. XI). Jak słusznie wskazuje Wasilewski, takie ujęcie pozycjonuje omawiany paradygmat w nurcie elitystycznym. „Jak każde podejście elitystyczne, paradygmat Fielda i Higleya przypisuje elitom kluczową rolę w procesie historycznym" (Wasilewski, 1990, s. 41).

Zdaniem autorów analizowanego paradygmatu na wiele szczegółowych pytań dotyczących składu, struktury czy charakteru elity funkcjonującej w danym państwie mogą dać odpowiedź jedynie szczegółowe badania empiryczne członków elity. Nawet to, „czy elity są spójne, zamknięte, oparte na kooptacji, konspiracji i tak dalej, to już są pytania, na które mogą odpowiedzieć jedynie badania empiryczne" (Higley, Field, Grøholt, 1976, s. 16). Według twórców neofunkcjonalnego paradygmatu elitystycznego tylko od konkretnych warunków historycznych i społecznych zależy nawet to, czy elity są grupami, czy tylko „zwykłymi kategoriami statystycznymi" (Higley, Field, Grøholt, 1976, s. 17). A skoro tak wiele cech elit (czy elity) zależy od konkretnej sytuacji społeczno-politycznej, to definicja elity może, a nawet powinna być minimalistyczna. „Możemy określić elity jako te osoby, które indywidualnie, regularnie i poważnie mają władzę wpływa- 
nia na rezultaty organizacyjne. Władza może zostać zdefiniowana jako zdolność do składania ofert lub czynienia gróźb, które są zdolne do zmiany motywacji osób - innych niż posiadacze władzy. Wprawdzie nie znamy żadnego sposobu, dzięki któremu władza mogłaby być bezpośrednio obserwowana i dokładnie zmierzona, zakładamy jednak, iż normalnie zawiera się w najwyższych szczeblach organizacji. Tak więc to organizacja tworzy 'elity"' (Higley, Field, Grøholt, 1976, s. 17). Najważniejsze, jak się wydaje, a zarazem wymagające dalszego wyjaśnienia, są w tej definicji dwa słowa: „regularnie” i „poważnie”. W związku z tym twórcy paradygmatu kilkakrotnie przytaczają w swych pracach, niestety ciągle jeszcze aktualny, przykład. Samotny terrorysta może wpłynąć na politykę danego państwa „poważnie”, ale już nie „regularnie”. Natomiast wyborca, którego aktywność polityczna sprowadza się tylko do uczestnictwa co kilka lat w akcie wyborczym, wpływa na politykę wprawdzie „regularnie”, ale już nie „poważnie”.

Podkreślanie roli instytucji dla tworzenia elity oczywiście przypomina koncepcję Charlesa Wrighta Millsa. W przeciwieństwie do elity, cała reszta społeczeństwa jest określana przez twórców neofunkcjonalnego paradygmatu elitystycznego jako „nie-elita” (non-elite). Taka dychotomiczna wizja struktury społecznej, z podziałem jedynie na elitę i masę, przypomina z kolei podejście „ojców założycieli” teorii elity (Mosca, Pareto, Michels). Najwyraźniej zdając sobie $\mathrm{z}$ tego sprawę, twórcy paradygmatu wskazują, iż w przeciwieństwie do klasyków uznają „wagę działania nie-elit, a paradygmat zajmuje pozycję pośrednią między paradygmatem marksistowskim a klasycznym elitystycznym" (Higley, Deacon, Smart, 1979, s. XI). Autorzy analizowanego paradygmatu opowiadają się więc za pozycyjną definicją elity, wskazującą na miejsce elity w strukturze społecznej i (oczywiście) na funkcje pełnione przez członków elity. Takie podejście jest obecnie o wiele częściej stosowane niż podejście decyzyjne (decision-making approach), analizujące decyzje podejmowane przez członków elity, czy podejście reputacyjne (reputational approach), badające autorytet, którym cieszą się członkowie elity - zarówno w opinii innych osób, jak i w swoim własnym mniemaniu.

Wskazana powyżej pozycyjna definicja elity podlegała później jedynie niewielkim modyfikacjom, które jednak nie zmieniały jej zasadniczego charakteru. „Elitę stanowią osoby zajmujące strategiczne pozycje w publicznych i prywatnych organizacjach biurokratycznych (np. w administracji państwowej), partiach politycznych, przedsiębiorstwach produkcyjnych, związkach zawodowych i innych organizacjach zawodowych, środkach masowego przekazu, instytucjach religijnych i oświatowych, zorganizowanych grupach protestu itp." (Field, Higley, 1980, s. 20). Niemniej zwolennicy paradygmatu zauważyli również znaczenie ruchów społecznych w świecie współczesnym. „Uważamy za elitę osoby zajmujące naczelne pozycje w potężnych organizacjach (publicznych i prywatnych) oraz we wpływowych ruchach społecznych, które w związku z tym są w stanie regularnie 
wpływać na [podejmowanie] strategicznych decyzji” (Higley, Hoffmann-Lange, Kadushin, Moore, 1991, s. 36). Tak więc, niewątpliwie słusznie, autorzy paradygmatu implicite przyjmują rozszerzone ujęcie władzy, uwzględniające nie tylko proces podejmowania decyzji, ale także zjawisko wpływu na podejmowanie decyzji (oczywiście na odpowiednio wysokim szczeblu). Równocześnie bowiem szczebel podejmowania decyzji (politycznych, ekonomicznych, militarnych itd.) jest bardzo ważny, gdyż twórcy neofunkcjonalnego paradygmatu elitystycznego koncentrują się wyraźnie na poziomie ogólnopaństwowym (czy ogólnonarodowym). Elity narodowe (national elites) to „osoby, które dysponują władzą wpływania (indywidualnie, regularnie i poważnie) na rezultaty polityczne na poziomie makro zorganizowanych społeczeństw" (Higley, Field, Grøholt, 1976, s. 17). Wskazanie na poważne, czyli inaczej doniosłe, konsekwencje działań i decyzji podejmowanych przez członków elity przypomina z kolei podejście Suzanne Keller. „Elity to jednostki i małe grupy zajmujące najwyższe pozycje w największych społecznych organizacjach (lub też najbogatszych w różnego rodzaju zasoby), które są w stanie wykorzystać potęgę tych organizacji do wpływania w sposób znaczący i systematyczny na polityczne rezultaty. Struktura elity odnosi się do składu społecznego, wzorów interakcji czy norm i wzorów zachowania danej elity" (Kahlberg, Higley, Pakulski, 1998, s. 108). Zdaniem autorów omawianego paradygmatu to właśnie aktywność i decyzje podejmowane przez członków elity wyznaczają charakter systemu politycznego danego państwa. „Nasz model zakłada, iż elity są odpowiedzialne za stworzenie instytucji politycznych i w związku z tym za charakter reżimu politycznego" (Kahlberg, Higley, Pakulski, 1998, s. 109). Jak wskazuje John Higley, elity funkcjonujące w danym państwie liczą najczęściej mniej niż dwa tysiące osób. „Jest to prawdopodobnie najbardziej właściwa liczba dla wszystkich krajów będących na etapie wczesnej nowoczesności, ale także dla prawie wszystkich państw współczesnych (z wyjątkiem tych najbardziej zaludnionych)" (Higley, 2010, s. 163). Według niego nawet najliczniejsza elita, funkcjonująca obecnie w USA, nie przekracza 10 tysięcy osób. Jednocześnie liczebność elit w państwach średniej wielkości (np. Francja, Australia, Niemcy) szacowana jest na około pięć tysięcy osób, podczas gdy w państwach o mniejszym zaludnieniu (np. Dania, Norwegia) oscyluje w granicach dwóch tysięcy - podobnie jak w państwach rozwijających się (Higley, Burton, 2006, s. 7).

\section{Klasyfikacja elity}

Jak wskazano już w tym szkicu, w ujęciu twórców i propagatorów neofunkcjonalnego paradygmatu elitystycznego funkcjonowanie elity (czy może raczej elit) $\mathrm{w}$ danym państwie nie tylko nie pozostaje $\mathrm{w}$ sprzeczności $\mathrm{z}$ występowaniem 
ustroju demokratycznego, ale stanowi też istotne kryterium klasyfikacji systemów o charakterze demokratycznym. Zanim jednak pojawi się klasyfikacja systemów o charakterze demokratycznym, należy zająć się typologią samych elit. Osoby tworzące elitę to najczęściej wybitne osobowości, wyróżniające się przynajmniej w jednej dziedzinie społecznej aktywności. Dlatego też członkowie elity danego społeczeństwa zazwyczaj są indywidualistami, a jedynie z konieczności zawierają kompromisy czy działają w zespole. „Osoby zajmujące strategiczne pozycje w różnego rodzaju organizacjach najczęściej cechują się bardzo silnym poziomem nieufności wzajemnie wobec siebie. Tworzą więc kliki czy frakcje" (Higley, Deacon, Smart, 1979, s. 9). Taka sytuacja jest oczywiście niekorzystna z punktu widzenia stabilności systemu politycznego - a to stanowi podstawową troskę wyrażaną przez twórców neofunkcjonalnego paradygmatu elitystycznego. Jednak zarówno w świecie współczesnym, jak i w mniej lub bardziej odległej historycznej przeszłości szczególnie często mamy do czynienia właśnie z konfliktami pomiędzy członkami elity. „Najczęściej występującym typem elity jest elita sfragmentaryzowana (nazywana też podzieloną, rozbitą lub zdezintegrowaną)" (Wasilewski, 1990, s. 33). Oczywiście występowanie w danym państwie elity sfragmentaryzowanej (disunified elite) przekłada się na brak stabilności całego systemu politycznego. „Wzajemny brak zaufania i strach to podstawowe cechy sfragmentaryzowanej struktury elity" (Higley, Deacon, Smart, 1979, s. 9). Zdaniem autorów omawianego paradygmatu elity sfragmentaryzowane występują szczególnie często równolegle z procesem tworzenia się państw narodowych. „Elita na szczeblu narodowym jest sfragmentaryzowana, kiedy jej członkowie (1) podzielają jedynie kilka (albo wcale) podejść do rozumienia właściwości zachowania politycznego oraz (2) jedynie sporadycznie i w sposób ograniczony angażują się we wzajemne interakcje" (Higley, Burton, 1989, s. 19). Postępowanie i działania członków elit sfragmentaryzowanych cechuje z reguły znaczny poziom wzajemnej nieufności, który rzecz jasna utrudnia (a niekiedy wręcz uniemożliwia) zawieranie porozumień politycznych czy szerszych koalicji (wyborczych bądź parlamentarnych). W przypadku elit sfragmentaryzowanych minimalny jest poziom strukturalnej integracji lub zgody w sprawie wspólnie podzielanych wartości (value consensus). „Stronnicy poszczególnych frakcji czy elit $\mathrm{w}$ różnych sektorach manifestują wzajemny brak zaufania, a także angażują się w niepohamowane (a często nawet gwałtowne) walki o dominację, które mają charakter gry o sumie zerowej lub nawet 'wojny politycznej"' (Higley, Burton, 2006, s. 14). Oczywiście taka sytuacja jest wysoce niekorzystna z punktu widzenia stabilności danego systemu społeczno-politycznego. „Osoby i frakcje funkcjonujące $\mathrm{w}$ ramach elity sfragmentaryzowanej są mocno podzielone i oddzielone od siebie, fundamentalnie nie zgadzają się w sprawach norm czy instytucji politycznych" (Higley, 2010, s. 165-166). Niewątpliwie trudno w sytuacji ciągłe- 
go konfliktu politycznego realizować jakikolwiek program polityczny. To trochę tak jak w szkole (nie mylić z uniwersytetem): kiedy nauczyciel ciągle musi uciszać klasę, to w rezultacie niczego (czy przynajmniej niewiele) nie będzie w stanie nauczyć. „Sfragmentaryzowana elita narodowa, która występuje najczęściej, wytwarza cały ciąg niestabilnych reżimów politycznych, które z reguły oscylują pomiędzy formami autorytarnymi a demokratycznymi” (Higley, Burton, 1989, s. 17). I to właśnie brak stabilności systemu politycznego (regime instability) stanowi „najważniejszą polityczną konsekwencję sfragmentaryzowania elity” (Higley, Burton, 1989, s. 20). Pomimo tak istotnych i negatywnych (przynajmniej dla stabilności systemu politycznego) konsekwencji sfragmentaryzowania elity nie wydaje się, aby miały one odejść w historyczną przeszłość i polityczny niebyt. „Elity sfragmentaryzowane, które tworzą reżimy autorytarne lub nieliberalne demokracje, rządziły w historycznej przeszłości i wydaje się, że tak pozostanie" (Higley, Burton, 2006, s. 3). W przypadku gdy w jakimś państwie mamy do czynienia ze stabilnymi instytucjami politycznymi, to jednocześnie „nie występują nieregularne przejęcia władzy wykonawczej na szczeblu rządowym ani wyraźny wpływ kręgów militarnych na proces podejmowania decyzji politycznych poprzez groźbę interwencji wojskowej" (Higley, 2010, s. 164). W związku z tym osobista kontrola nad wojskiem i siłami policyjnymi - a poprzez te instytucje manipulacja światem polityki - stanowi jeden z ważniejszych aspektów działania elity sfragmentaryzowanej. John Higley wskazuje na cały szereg przykładów takich procesów znanych z dziewiętnasto- czy dwudziestowiecznej Hiszpanii, Portugalii lub krajów Ameryki Łacińskiej.

Skoro występowanie elit sfragmentaryzowanych, jako rezultat głębokich podziałów społecznych albo wielu historycznych „zaszłości”, skutkuje nie tylko brakiem porozumienia bądź integracji pomiędzy elitami, ale również brakiem stabilności całego systemu politycznego danego państwa, autorzy neofunkcjonalnego paradygmatu elitystycznego stawiają pytanie o możliwość i warunki integracji elit występujących $\mathrm{w}$ danym państwie, społeczeństwie czy narodzie. Według nich mogą być dwie podstawy takiej integracji: wspólnie „wyznawana” jedna ideologia lub wspólnie podzielane podstawowe wartości (szczególnie wartości polityczne). Elity zintegrowane ideologicznie (ideological unified elites) tworzą ustroje o charakterze totalitarnym, podczas gdy elity zintegrowane wokół wartości (consensual unified elites) stanowią podstawę stabilnej i skonsolidowanej demokracji (consolidated democracy), jako najbardziej pożądanego ustroju wśród systemów o charakterze demokratycznym. Oczywiście można zadać pytanie, czy system totalitarny powstały w wyniku ideologicznej integracji elit jest lepszy od systemu autorytarnego (czy tzw. nieliberalnej demokracji), będącego rezultatem sfragmentaryzowania elit działających w danym państwie. Ale twórcy neofunkcjonalnego paradygmatu elitystycznego takiego pytanie nie zadają 
(a przynajmniej się z nim nie spotkałem). Pamiętając jednak o naszych polskich doświadczeniach z okresem Polski Ludowej, wydaje się, że cena za ideologiczną integrację elit może być zbyt duża. „Drugi [obok elit sfragmentaryzowanych - przyp. M.Ż.] podstawowy typ elit to elity zintegrowane (zunifikowane) wokół jedynej ideologii. Mamy z nimi do czynienia wówczas, gdy zwarty ruch społeczny o jasno wykrystalizowanej ideologii zdoła obsadzić swoimi ludźmi strategiczne pozycje organizacyjne" (Wasilewski, 1990, s. 33). Niewątpliwym plusem takiego rozwiązania jest już sama integracja elity (a więc brak istotnych konfliktów), a w rezultacie stabilność samego systemu politycznego, ale dokonana za cenę (mniej lub bardziej nasilonego) ograniczenia praw i swobód obywatelskich w danym państwie. W takim systemie brak jest również konkurencji, zwłaszcza zaś brak jest wolnych, nieskrępowanych i konkurencyjnych wyborów (Higley, Moore, 1981, s. 583). „Wyznacznikiem elity zintegrowanej ideologicznie jest jednolite wyznawanie jednej, określonej ideologii przez wszystkie osoby należące do elity. Jej jedność jest urzeczywistniona przez uniemożliwienie osobom należącym do rywalizujących elit publicznego zajmowania odmiennego stanowiska w sprawach politycznych czy wyrażania innych przekonań politycznych" (Higley, Field, Grøholt, 1976, s. 29). Oczywiście można dyskutować, czy i na ile w systemach totalitarnych (a może raczej w ustrojach o charakterze totalitarnym) mogły w ogóle utworzyć się i przetrwać elity konkurencyjne wobec elity sprawującej pełnię władzy. Niewątpliwie „klasyczne” reżimy totalitarne - stalinowski Związek Sowiecki, hitlerowska Trzecia Rzesza czy faszystowskie Włochy doby Mussoliniego - wolne były od tego rodzaju dylematów (i od wielu innych zresztą też). Niemniej w komunistycznej (czy od epoki Gierka już raczej tylko socjalistycznej) Polsce cały czas funkcjonowała - lepiej lub gorzej - zorganizowana opozycja, co stało się jednym $\mathrm{z}$ istotnych czynników upadku systemu „realnego socjalizmu” w 1989 roku. Trudno natomiast polemizować z twierdzeniem o decydującej roli partii w systemach o charakterze totalitarnym. W przypadku systemu opartego na elicie zintegrowanej ideologicznie „występuje jedna, wszechstronna partia polityczna, do której należą wszystkie osoby zajmujące pozycje elity i z którą powiązane są wszystkie stanowiska elity i kanały wpływu" (Higley, Deacon, Smart, 1979, s. 10). Również pod tym względem Polska Ludowa odchodziła od klasycznego, zaprezentowanego powyżej, modelu. Obok dominującej PZPR (Polska Zjednoczona Partia Robotnicza) działało przecież ZSL (Zjednoczone Stronnictwo Ludowe) czy SD (Stronnictwo Demokratyczne). Określano je wprawdzie pół żartem, pół serio mianem „przystawek”, trudno jednak w tym przypadku mówić (lub pisać) o jednej, jedynej partii. Niemniej otrzymujemy „obraz jednej, homogenicznej grupy przywódczej” (Higley, Field, Grøholt, 1976, s. 29). Wskazana struktura elity, oparta na jednolicie wyznawanej ideologii, „tworzy bardzo stabilny reżim polityczny” (Higley, Deacon, Smart, 
1979, s. 10). Również jednak ze stabilnością reżimów o charakterze totalitarnym różnie bywa - tysiącletnia Trzecia Rzesza przetrwała tylko nieco ponad 12 lat. Jak wskazuje John Higley, polityczną stabilność można osiągnąć jedynie w przypadku funkcjonowania zintegrowanej elity (united elite). „Jednym rodzajem jest elita zintegrowana ideologicznie (ideologically united elite), która cechuje się jednomyślnym wyznawaniem przez jej członków jednolitej, dokładnie zdefiniowanej ideologii" (Higley, 2010, s. 164). Jednocześnie stabilność systemu nie musi ucierpieć w sytuacji (znanej nam chociażby z PRL-u), kiedy to ideologiczna jednolitość jest narzucona siłą i/lub występuje bardziej na poziomie deklarowanych niż rzeczywiście realizowanych postaw. To partia pilnuje jednolitości ideologicznej. „Przynajmniej na pozór pojawia się też ogólny konsensus w sprawie wartości pomiędzy wszystkimi grupami elity" (Higley, Moore, 1981, s. 581). Charakterystyczne, że nawet w przypadku elity zintegrowanej ideologicznie sama ideologia jest często traktowana jedynie instrumentalnie. „Istota i zawartość jednolitej ideologii, która określa elitę zintegrowaną ideologicznie, nie ma większego znaczenia analitycznego. [...] ma też niewielkie znaczenie dla narzuconej jedności, która dominuje wśród członków elity" (Higley, 2010, s. 165).

Powstanie elit ideologicznie zintegrowanych ma jednak niewiele wspólnego z pokojowymi przemianami w danym państwie. „Elity zintegrowane ideologicznie są pokłosiem rewolucji (socjalistycznych lub faszystowskich) albo międzynarodowego konfliktu zbrojnego" (Field, Higley, 1980, s. 39). Tak więc, zdaniem twórców neofunkcjonalnego paradygmatu elitystycznego, elity zintegrowane ideologicznie tworzą się na jeden z dwóch sposobów. Po pierwsze, to „zwycięstwa sił radykalnych w sytuacjach rewolucyjnych" (tak jak w Rosji, Włoszech, Niemczech, Chinach czy na Kubie), a po drugie, ,jest to narzucone społeczeństwom pokonanym w walce, tak jak w Europie Wschodniej czy Korei Północnej po II wojnie światowej” (Higley, Moore, 1981, s. 581). Myśl tę rozwija już prawie 30 lat później sam John Higley, pisząc, iż „Elity zintegrowane ideologicznie powstają w sytuacjach rewolucyjnych, które sprawiają, że ruch dogmatycznie wyrażający specyficzną ideologię czy wiarę jest w stanie stłumić i wyrugować wcześniej istniejące elity. Przykłady stanowią Rosja 1917-1921, Włochy 1922-1925, Niemcy 1933-1934, Korea Północna 1946-1948, Chiny po 1949, Kuba 19591961 i Iran 1979-1981. Elity zintegrowane ideologicznie mogą się także wyłonić wtedy, gdy zewnętrzna potęga posiadająca takie elity narzuca ich klony podbitemu (czy w inny sposób podporządkowanemu) krajowi, jak Związek Radziecki uczynił to w Niemczech Wschodnich i innych krajach Europy Wschodniej po II wojnie światowej" (Higley, 2010, s. 166). Pewnie jeszcze długo będzie nam trudno pogodzić się w Polsce z określaniem faszystowskiego „marszu na Rzym” czy dojścia Hitlera do władzy w kategoriach rewolucji. Niemniej już 15 lat temu Michael Mann postrzegał nie tylko komunistów, ale również faszystów czy nazi- 
stów właśnie w kategoriach władzy rewolucyjnej (revolutionary power) (Mann, 2004). Z kolei najnowsze badania historyczne pokazują coraz wyraźniej, że rewolucja październikowa (1917 r.) w Rosji, w przeciwieństwie do rewolucji lutowej, miała wiele cech „Zwykłego” zamachu stanu (Fitzpatrick, 2017).

Niewątpliwie oparcie integracji elit funkcjonujących w danym państwie nie na wspólnie wyznawanej ideologii, lecz na podzielanych wspólnie wartościach (zwłaszcza odnoszących się do podstaw demokratycznego państwa prawa) stanowi najbardziej pożądany typ elity - i to nie tylko w opinii twórców neofunkcjonalnego paradygmatu elitystycznego. Obok elit sfragmentaryzowanych czy zintegrowanych ideologicznie, „Trzeci rodzaj to elity zintegrowane wokół zespołu fundamentalnych wartości, wspólnych dla wszystkich grup składających się na elitę" (Wasilewski, 1990, s. 35). To inaczej elity konsensualnie zintegrowane (consensually unified elites). W przeciwieństwie do poprzednio omawianego rodzaju elity (ideological unified elites), istotnym elementem jest w tym przypadku dobrowolność procesu integracji elity. Ten typ elity „obejmuje dobrowolną integrację pozycji elity i kanałów wpływu, tak aby członkowie elity mogli wpływać na te kwestie polityczne, które są dla nich szczególnie ważne" (Higley, Deacon, Smart, 1979, s. 11). Oczywiście integracja elity wokół wartości nie zakłada (ani nawet nie dąży do) jednomyślności we wszystkich kwestiach politycznych, gdyż wtedy mielibyśmy do czynienia z elitą zintegrowaną ideologicznie. Jednak pomimo zajmowania niejednokrotnie zupełnie przeciwnych stanowisk w wielu kwestiach, członkowie elit konsensualnie zintegrowanych powszechnie uznają podstawowe zasady funkcjonowania systemu demokratycznego. „Dotrzymują więc całego zestawu (zwykle niespisanych) zasad zachowania politycznego. W konsekwencji konflikty polityczne są z reguły umiarkowane, a instytucje polityczne są stabilne i odporne na prostsze i brutalniejsze formy przechwycenia władzy, które charakteryzują elity o strukturze sfragmentaryzowanej" (Higley, Deacon, Smart, 1979, s. 11). Nic więc dziwnego, że stabilne reżimy demokratyczne (zwłaszcza $\mathrm{w}$ formie demokracji skonsolidowanej) opierają się właśnie na elitach konsensualnie zintegrowanych. „Elita narodowa jest konsensualnie zintegrowana (consensually unified), kiedy jej członkowie (1) podzielają, w dużej mierze milczący, konsensus w sprawie zasad i przepisów zachowania politycznego oraz (2) uczestniczą w mniej lub bardziej całościowo zintegrowanej strukturze interakcji, która daje im stosunkowo niezawodny i skuteczny dostęp do siebie wzajemnie, jak też i do najważniejszych decydentów" (Higley, Burton, 1989, s. 19). Niewątpliwie więc warunkiem sine qua non występowania w danym państwie elity konsensualnie zintegrowanej jest odpowiednie podejście do samej polityki. I bynajmniej nie chodzi tutaj o zakwestionowanie klasycznej (jeszcze weberowskiej) definicji polityki jako dążenia do zdobycia i utrzymania władzy. Konkurent w tym dążeniu (inny przywódca czy inna partia) powinien być traktowany jako współzawodnik, 
a nie jako przeciwnik czy nawet wróg - tak jak w koncepcji tzw. polityki agrarnej, czyli „kto kogo do ziemi” (jak mawia mecenas Ryszard Kalisz). W końcu we współczesnym ustroju demokracji przedstawicielskiej nic nie jest trwałe (ani tym bardziej na wieczność). Dzisiejsza opozycja może jutro (czyli w najbliższych wyborach) przejąć władzę i potraktować nas tak, jak sama była traktowana. Opierając się bowiem na ujęciu Giovanniego Sartoriego (Sartori, 1987, s. 224), „członkowie elity postrzegają rezultaty decyzji jako 'grę o sumie dodatniej', natomiast 'politykę jako przetarg', a nie jako 'grę o sumie zerowej' czy 'politykę jako wojnę' (Higley, Burton, 1989, s. 19). Ale to właśnie w modelu elity konsensualnie zintegrowanej występują nie tylko konflikty, ale mamy również do czynienia $z$ dążeniem do kompromisu. „Kluczową cechą elit zintegrowanych konsensualnie jest ich zdolność do monitorowania i pohamowania pewnych kwestii, których otwarte i dogmatyczne ujawnienie stworzyłoby zgubny konflikt" (Field, Higley, 1980, s. 37). Następnie John Higley jeszcze bardziej „wyklarował” swoją koncepcję teoretyczną: „Wprawdzie członkowie elity nie zgadzają się ze sobą (a nawet przeciwstawiają się sobie) w limitowanych starciach o dominację, lecz władza jest podzielona w taki sposób, aby mieli oni wystarczający wpływ na podejmowanie decyzji politycznych, co powstrzymuje ich od przekształcenia opozycji w próbę siłowego przejęcia rządu. W związku z tym instytucje polityczne są stabilne w długim okresie czasu" (Higley, 2010, s. 165). Zdaniem autorów omawianego paradygmatu wszystkie elity konsensualnie zintegrowane są w pewien sposób do siebie podobne, „Mają bowiem podobne struktury, składające się z sieci osobistych interakcji (bardziej inkluzywnych niż opartych na zasadach klasowych), obejmujące bardziej rozległe i scentralizowane powiązania między wszystkimi głównymi grupami elitarnymi, niż przedstawiają to modele elity pluralistycznej, elity władzy czy klasy rządzącej” (Higley, Moore, 1981, s. 581). Modele te zostały zaprezentowane w piątej (i zarazem ostatniej) części niniejszego szkicu.

W związku z tym, iż model elit konsensualnie zintegrowanych jest tak istotny dla właściwego funkcjonowania systemu demokracji przedstawicielskiej, warto zająć się także sposobami, metodami i warunkami osiągnięcia tak pożądanej sytuacji - tym bardziej że twórcy neofunkcjonalnego paradygmatu elitystycznego poświęcili tej kwestii dużo uwagi (nawet w osobnych artykułach naukowych). Położono akcent przede wszystkim na „trzy sposoby, dzięki którym powstają elity konsensualnie zintegrowane. Jedynie w zupełnie wyjątkowych okolicznościach wojujące ze sobą frakcje, które tworzą elitę sfragmentaryzowaną, niekiedy osiągają konsensualną integrację dzięki dobrowolnemu wyklarowaniu i wyciszeniu najważniejszych dzielących ich różnic, a także zgadzają się na współpracę w ramach już istniejących instytucji politycznych" (Higley, Moore, 1981, s. 581). Jest to bardzo ważny dla omawianego paradygmatu przypadek tzw. porozumienia pomiędzy elitami (elite settlements), który został następnie szerzej 
przeanalizowany przez twórców neofunkcjonalnego paradygmatu elitystycznego. Na razie - w cytowanym artykule z 1981 roku - wskazano jedynie na kilka przykładów takiego właśnie porozumienia (Anglia 1688-1689; Szwecja 1809; Meksyk 1933; Kolumbia i Wenezuela pod koniec lat 50. XX wieku), ale katalog porozumień między elitami ulegał ciągłemu rozszerzaniu - obejmując około 20 państw (w tym również tych $\mathrm{z}$ regionu Europy Środkowo-Wschodniej). Wracając jednak do trzech dróg tworzenia elit konsensualnie zintegrowanych: „Druga [droga], to kiedy elity kolonialne (czy rodzime) osiągały czasami konsensualną integrację, funkcjonując w ramach samorządowych instytucji politycznych w koloniach lub terytoriach zależnych" (Higley, Moore, 1981, s. 581). Przykładami mogą być takie kraje jak: USA, Kanada, Australia, Indie bądź Malezja. „Elity konsensualnie zintegrowane wywodzą się także z procesu uzyskania niepodległości przez byłe kolonie, w których elity lokalne (czy rodzime) były w stanie praktykować limitowaną i ograniczaną politykę samorządową, prowadząc jednocześnie walkę o niepodległość, która jednoczyła działaczy" (Higley, 2010, s. 167). Charakterystyczne, że wszystkie podane wyżej przykłady to kolonie brytyjskie, a nie na przykład francuskie (o belgijskich lub holenderskich nie wspominając). Uznano więc znaczenie aktywności samorządowej dla edukacji obywatelskiej. „Trzecia [droga], to kiedy w państwach, które osiągnęły wysoki poziom rozwoju społeczno-gospodarczego, wraz z występowaniem elit sfragmentaryzowanych wystąpił proces erozji masowego poparcia dla bardziej radykalnych frakcji elity (zwykle o lewicowym charakterze). W celu utrzymania poparcia te radykalne frakcje stopniowo uspokoiły swe programy i cele polityczne, dzięki czemu uformowała się elita konsensualnie zintegrowana" (Higley, Moore, 1981, s. 581). W tym miejscu wskazano już jednak tylko na przykłady państw europejskich: Norwegia i Dania w latach 30. XX wieku, a Austria, RFN oraz Belgia w latach 50. i 60. XX wieku. Wszędzie tam stworzono stabilny system polityczny i to przy zachowaniu (a nawet rozwoju) wolności obywatelskich. Przedstawione powyżej trzy sposoby tworzenia elit konsensualnie zintegrowanych dotyczyły wyjścia z poziomu elit sfragmentaryzowanych. Niemniej można także podać przykłady państw, które przeszły (najczęściej dość szybką i gwałtowną) transformację z poziomu elit zintegrowanych ideologicznie do modelu elit konsensualnie zintegrowanych. Nastąpiło to jednak w wyniku przegranej wojny (II wojny światowej) w takich państwach jak: Austria, Niemcy czy Włochy (Burton, Higley, 1987, s. 297). Jednocześnie w najnowszych pracach twórców neofunkcjonalnego paradygmatu elitystycznego pojawia się jeszcze „inna droga tworzenia się elit konsensualnie zintegrowanych [...], konwergencja elity (elite convergence). W krajach, które dokonały tranzycji w kierunku demokratycznych wyborów, przeciwne sobie obozy i frakcje tworzące elitę sfragmentaryzowaną mogą rozpocząć zbliżanie się, jeśli niektóre z elit utworzą szerszą koalicję polityczną, 
która zmobilizuje tak wielu wyborców, aby kilkakrotnie wygrywać wybory" (Higley, 2010, s. 167). John Higley wskazał w tym miejscu na cztery przykłady takiego rozwiązania politycznego: Francja (po powrocie do władzy generała de Gaulle’a w 1958 roku), Włochy (kiedy socjaliści stworzyli koalicję z chrześcijańską demokracją w 1963 roku), RFN wraz z koalicją CDU - CSU - FDP (1953 r.) oraz „Japonia po 1964 roku, kiedy to liberalni demokraci stworzyli (wraz z partiami centrowymi) elektoralnego molocha" (Higley, Burton, 2006, s. 3). Zdaniem twórców omawianego paradygmatu konwergencja elity wydaje się stanowić najbardziej realne, przyszłościowe rozwiązanie i metodę tworzenia elit konsensualnie zintegrowanych. Porozumienia między elitami są bowiem bardzo rzadkie i wymagają równoczesnego spełnienia całego szeregu warunków (o czym poniżej), a z kolei na proces wychodzenia ze statusu kolonii czy terytoriów zależnych jest już zdecydowanie za późno - żyjemy przecież w świecie postkolonialnym. Jednocześnie jednak „konwergencje wśród elit sfragmentaryzowanych do modelu konsensualnie zintegrowanego wymagają znaczącego poziomu dobrostanu i ekonomicznego rozwoju" (Higley, 2010, s. 167). Generalnie zresztą zaprezentowane przez twórców neofunkcjonalnego paradygmatu elitystycznego typy elit okazują się dosyć trwałe - w okresie ostatnich 350 lat jedynie około 45 elit na świecie przeżyło proces transformacji. „Elity konsensualnie zintegrowane powstały w wyniku porozumienia lub konwergencji w około 30 krajach w ciągu ostatnich 350 lat. Rewolucyjne transformacje $\mathrm{z}$ elit sfragmentaryzowanych do konsensualnie zintegrowanych były jeszcze rzadsze - zaledwie około 10 przypadków" (Higley, Burton, 2006, s. 28).

Jak już jednak wskazano w niniejszym szkicu, najważniejszym sposobem dojścia do modelu elit konsensualnie zintegrowanych jest porozumienie między elitami (oczywiście nie wszystkimi, a jedynie najważniejszymi i najbardziej wpływowymi) funkcjonującymi w danym państwie (elite settlements). „Porozumienia między elitami obejmują szerokie kompromisy między (wcześniej zwalczającymi się) frakcjami elity, co owocuje polityczną stabilizacją i w związku z tym tworzy niezbędny warunek wstępny dla długotrwałej praktyki demokracji przedstawicielskiej" (Burton, Higley, 1987, s. 295). W artykule tym, specjalnie poświęconym kwestii porozumienia między elitami (elite settlements), wskazano na cztery „klasyczne” przypadki takiego porozumienia: Anglia 1688-1689, Szwecja 1809, Kolumbia 1957-1958 oraz Wenezuela 1958. Szczególnie charakterystyczny wydaje się pierwszy z podanych przykładów, gdyż w tym czasie Anglia znajdowała się mniej więcej wiek przed rozpoczęciem rewolucji przemysłowej, a to właśnie do społeczeństw przemysłowych, zwłaszcza zaś postindustrialnych miał stosować się omawiany paradygmat. W latach 1688-1689 Anglia przeżywała tzw. Wspaniałą Rewolucję (Glorious Revolution), która może i była wspaniała - jak pokazują chociażby dwa obrazy Canaletta przedstawiające wpłynięcie flo- 
tylli Wilhelma Tamizą do Greenwich i dalej do Londynu (w National Maritime Museum), ale na pewno nie była to żadna rewolucja. To po prostu „zmiana warty" i panującej dynastii, wyznaczająca jednak kres marzeń o władzy absolutnej i rozpoczynająca epokę monarchii parlamentarno-konstytucyjnej. Z kolei porozumienie się elit w Szwecji zostało wywołane przez utratę Finlandii na rzecz Rosji (w 1808 r.). W opublikowanym 11 lat później szkicu otrzymujemy już listę dwunastu elite settlements, obejmującą także Polskę i Węgry (1989 r.) oraz RPA (1992-1993) (Burton, Higley, 1998, s. 50-51). Natomiast w książce wydanej w roku 2006 wyliczono już 14 przypadków porozumienia między elitami (dodatkowo Korea Południowa [1987] i Słowenia [1990-1991]) (Higley, Burton, 2006, s. 90). „Porozumienie między elitami to nagły i przemyślany kompromis między elitami politycznymi w sprawie podstawowych kwestii. Przed porozumieniem elity nie zgadzały się w sprawie legitymacji instytucji rządowych, angażowały się w niepohamowane starcia o dominację i postrzegały politykę na zasadzie zwycięzca bierze wszystko. Po porozumieniu członkowie elity i całe grupy nadal są związane ze sprzecznymi partiami, ruchami czy przekonaniami, ale podzielają konsensus co do znaczenia instytucji oraz kodów i zasad politycznego współzawodnictwa” (Burton, Higley, 1998, s. 47).

Oczywiście najczęściej trudno jest nakłonić skonfliktowane elity, funkcjonujące $\mathrm{w}$ danym państwie, do zawarcia takiego porozumienia. W związku z tym elite settlements wymaga równoczesnego spełnienia kilku istotnych warunków. Przede wszystkim w danym państwie musi wystąpić ostry kryzys (z reguły społeczno-ekonomiczny), którego dotychczasowa ekipa sprawująca władzę nie jest w stanie samodzielnie rozwiązać. „Dwa zestawy okoliczności mają, jak się wydaje, decydujące znaczenie: (1) występowanie intensywnego, kosztownego, ale niemożliwego do rozwiązania konfliktu między głęboko podzielonymi elitami politycznymi; i (2) skupienie się elit w dwóch lub trzech odrębnych i zantagonizowanych obozach, każdy o dość dużej trwałości i dobrze artykułowanych interesach, organizacji i przywództwie, co pozwala na wywołanie dużych szkód przeciwnikowi politycznemu" (Burton, Higley, 1998, s. 49). Następnie istotna jest też szybkość procesu porozumienia między elitami - „elite settlements dokonują się szybko albo wcale" (Burton, Higley, 1987, s. 299). W kolejnych tekstach twórców neofunkcjonalnego paradygmatu elitystycznego kwestia szybkości procesu negocjacji została zresztą rozwinięta i uściślona: „Porozumienia dokonują się ze znaczną szybkością, rzadko trwając dłużej niż kilka tygodni czy miesięcy; im więcej czasu zabiera proces porozumienia, tym łatwiej może dojść do działań blokujących ze strony elit pozostających poza niewielkim gronem liderów" (Burton, Higley, 1998, s. 55). Proces porozumienia się między elitami musi zostać poprzedzony specjalnymi negocjacjami (z reguły prowadzonymi w sekrecie) pomiędzy przywódcami najważniejszych grup elitarnych funkcjonujących $\mathrm{w}$ da- 
nym państwie. „Proces, poprzez który dokonuje się porozumienie, zawiązuje się zasadniczo wśród niewielkiego kręgu przywódców” (Burton, Higley, 1998, s. 55). To zresztą oczywiste, gdyż w przeciwnym przypadku trudno byłoby o zachowanie w sekrecie toczących się rokowań politycznych. Przywódcy ci powinni mieć za sobą już doświadczenie polityczne i cechować się skłonnością do kompromisu. Dlatego też rokowania w Magdalence, poprzedzające porozumienie Okrągłego Stołu w Polsce w 1989 roku, stanowiły niezbędny element procesu elite settlements - przynajmniej w ujęciu twórców neofunkcjonalnego paradygmatu elitystycznego. Porozumienie musi zakończyć się formalnym spisaniem uzgodnionych treści. Wreszcie elity muszą mieć znaczny poziom autonomii i niezależności od możliwych nacisków ze strony szerszych mas społecznych, tak aby spokojnie uzgodnić między sobą najważniejsze kwestie sporne - jeszcze przed przedstawieniem ich szerszej opinii publicznej (Burton, Higley, 1987, s. 299301). I to właśnie „potrzeba rzeczywistej autonomii elity pomaga nam zrozumieć, dlaczego porozumienia między elitami występują tak rzadko w historii nowożytnej i w świecie współczesnym" (Burton, Higley, 1987, s. 301). To porozumienia między elitami stanowią istotną (a zwłaszcza najbardziej znaną) drogę tworzenia systemu demokracji skonsolidowanej (consolidated democracy), która - jako najbardziej pożądana forma współczesnej demokracji - zostanie przybliżona w kolejnej części niniejszego szkicu. „Porozumienia między elitami mają dwie zasadnicze konsekwencje: tworzą wzory współzawodnictwa - otwartego, ale pokojowego - między wszystkimi głównymi frakcjami elity oraz dokonują transformacji niestabilnych reżimów politycznych, w których często i nieregularnie występują siłowe przejęcia władzy wykonawczej, w stabilne systemy polityczne" (Burton, Higley, 1987, s. 295). Zdaniem Johna Higleya występowanie modelu elity konsensualnie zintegrowanej jest niezbędne do praktycznego funkcjonowania systemu demokratycznego w świecie współczesnym. „Tylko bowiem taka elita jest w stanie skutecznie zarządzać sprzecznymi interesami, których wyrażanie (otwarte i dogmatyczne) mogłoby doprowadzić do niszczących wewnętrznych konfliktów" (Higley, 2010, s. 170). Funkcjonowanie na szczeblu ogólnopaństwowym elity konsensualnie zintegrowanej stanowi warunek wprawdzie konieczny, ale jednak niewystarczający ukształtowania się stabilnego systemu demokratycznego. „Elita konsensualnie zintegrowana przetrwa bowiem tylko tak długo, dopóki jej członkowie będą mieli wolę i polityczną zdolność do powstrzymywania potencjalnie głębokich konfliktów i będą w stanie sprawnie zarządzać problemami politycznymi i społecznymi” (Higley, Moore, 1981, s. 581).

Zupełnie drugorzędne znaczenie dla omawianego paradygmatu mają elity nie w pełni zintegrowane (imperfectly united elites). Obok, omówionych już w niniejszym szkicu, elit sfragmentaryzowanych, elit zintegrowanych ideologicznie czy konsensualnie, „czwartym, pobocznym lub przejściowym typem elit są elity 
nie w pełni zintegrowane (częściowo zjednoczone). [...] Elita częściowo zjednoczona, w przeciwieństwie do trzech poprzednich, nie ma zdolności samotrwania. Albo przekształci się w elitę konsensualnie zintegrowaną, albo "powróci« do elity sfragmentaryzowanej" (Wasilewski, 1990, s. 36). Elity nie w pełni zintegrowane „różnią się od elit konsensualnie zintegrowanych, gdyż jedność i wzajemne zaufanie występują głównie wśród centroprawicowych ugrupowań politycznych, nie obejmując znacznych, widocznych i oddzielnych frakcji elity, zwykle o proweniencji socjalistycznej" (Higley, Field, Grøholt, 1976, s. 37). W związku z tym w takim modelu często zdarzają się rozruchy czy inne gwałtowne niepokoje społeczne, co oczywiście nie przyczynia się do osiągnięcia stabilności politycznej. Przykładami takiego modelu może być Japonia po zakończeniu amerykańskiej okupacji (po II wojnie światowej) czy Belgia przez większą część swego istnienia jako suwerenne państwo (lata 1830-1962), a także Włochy po II wojnie czy Francja w latach 60. i 70. XX wieku (Field, Higley, 1980, s. 40). Podstawową cechą elity nie w pełni zintegrowanej jest jej nietrwałość - lokując się między modelem elit sfragmentaryzowanych a modelem elit konsensualnie zintegrowanych, najczęściej jednak powraca do stanu fragmentacji (dezintegracji) elity. Jedynie wyjątkowo elity nie w pełni zintegrowane mogą przekształcić się w elity konsensualnie zintegrowane - tak jak można to było obserwować w Danii i Norwegii w latach 30 . XX wieku.

\section{Klasyfikacja systemów demokratycznych}

Jak już wskazano w niniejszym szkicu, zdaniem twórców neofunkcjonalnego paradygmatu elitystycznego nie tylko można pogodzić występowanie elity $\mathrm{z}$ funkcjonowaniem systemu demokratycznego, ale też elita społeczna (The Elite) - a szczególnie jej cechy i relacje pomiędzy członkami elity czy grupami elitarnymi - stanowi jedno z kryteriów klasyfikacji systemów demokratycznych. A dokładniej jedno $\mathrm{z}$ dwóch kryteriów, gdyż obok możliwości współpracowania ze sobą różnych osób czy grup tworzących elitę mamy także (jako drugie kryterium) gwarancje dla swobód i wolności obywatelskich wraz z możliwością powszechnego udziału $\mathrm{w}$ procedurach demokratycznych. $\mathrm{W}$ ramach omawianego paradygmatu kryteria te nie są jednak stopniowalne, lecz występują (lub nie) w układzie zero-jedynkowym. Otrzymujemy więc cztery systemy o charakterze demokratycznym, rozpoczynając od najbardziej pożądanego rozwiązania: demokracja skonsolidowana (consolidated democracy), demokracja nieskonsolidowana (unconsolidated democracy), stabilna demokracja ograniczona (stable limited democracy) oraz pseudodemokracja (quasi-democracy), gdzie żadne ze wspomnianych powyżej dwóch kryteriów nie jest spełnione. 
Oczywiście twórcy i propagatorzy omawianego paradygmatu najwięcej uwagi poświęcili pierwszemu (najbardziej oczekiwanemu i pożądanemu) typowi systemów demokratycznych, czyli demokracji skonsolidowanej. Jest to system bardzo trwały i stabilny, ponieważ został oparty na porozumieniu wszystkich (a przynajmniej najważniejszych) elit działających w danym państwie w sprawie korzyści wynikających z przestrzegania zasad demokratycznych. „Kluczem do stabilności i przetrwania systemu demokratycznego jest w naszym przekonaniu ustanowienie zasadniczego konsensusu wśród elit dotyczącego zasad demokratycznej gry politycznej oraz wartości instytucji demokratycznych" (Burton, Gunther, Higley, 1992, s. 3). Jak wskazują twórcy omawianego paradygmatu, demokracja skonsolidowana „to system rządów, który spełnia wszystkie proceduralne kryteria demokracji, w którym ponadto wszystkie znaczące politycznie grupy akceptują istniejące instytucje polityczne i demokratyczne reguły gry. Jest to oczywiście także typ idealny - zawsze istnieją przynajmniej niewielkie grupy dysydentów, które nie spełniają wyżej wymienionych warunków" (Burton, Gunther, Higley, 1995, s. 16). Analizując państwa, gdzie funkcjonuje system demokracji skonsolidowanej, autorzy zauważają, że „obejmują one zarówno specyficzne cechy elity, jak i masy. Po pierwsze, wszystkie istotne grupy i frakcje elity podzielają konsensus w sprawie zasad i kodów zachowania politycznego i znaczenia instytucji politycznych oraz są strukturalnie zintegrowane poprzez rozległe sieci formalnych i nieformalnych powiązań, które umożliwiają im wpływanie na podejmowanie decyzji i dzięki temu na pokojową obronę i promocję swych grupowych interesów. [...] Po drugie, występuje także (i to na dużą skalę) masowe uczestnictwo w wyborach i innych procesach instytucjonalnych" (Burton, Gunther, Higley, 1992, s. 4).

System demokracji skonsolidowanej przypomina również pojęcie poliarchii, wprowadzone i rozwijane w szeregu prac przez Roberta Dahla (Dahl, 1971). Pojęcie to zostało zastosowane także przez twórców i propagatorów neofunkcjonalnego paradygmatu elitystycznego. „Skonsolidowane demokracje to obieralne poliarchie, w których otwarta, pokojowa, polityczna kontestacja i partycypacja stanowi jedyną dostępną możliwość [the 'only game in town']" (Higley, Pakulski, 1999, s. 117). System demokracji skonsolidowanej opiera się w znacznej mierze na spójności elity, przejrzystych wzorach selekcji i cyrkulacji elity oraz na relacjach elity $z$ osobami i grupami społecznymi nienależącymi do elity. Oczywiście w stabilnym systemie demokracji przedstawicielskiej zarówno sama elita, jak i poszczególni jej członkowie okresowo poddają się testowi wyborczemu. Rzecz jasna, wybory na wszystkich szczeblach muszą być nieskrępowane, wolne, a ich wynik powszechnie uznany i obowiązujący - aby można było mówić o występowaniu demokracji skonsolidowanej. Można jednak też próbować określić system demokracji skonsolidowanej a contrario: „Sta- 
bilna demokracja określona przez to, czym nie jest, cechuje się z jednej strony brakiem koncentracji absolutystycznej władzy, a z drugiej strony charakteryzuje się brakiem bezpośredniego mieszania się (przez masową publikę czy partykularne elitarne grupy) $\mathrm{w}$ jasno określony proces podejmowania decyzji, przeprowadzony przez elitę" (Higley, Pakulski, 1999, s. 118-119). W związku z tym dla właściwego funkcjonowania systemu demokracji skonsolidowanej istotne jest, aby elity były nie tylko odpowiedzialne, ale i profesjonalne. Ważna jest także spójność elity, która „jest nie tylko podstawą skutecznego przywództwa, ale stanowi również warunek wstępny stabilnego i pokojowego politycznego współzawodnictwa, które odróżnia demokracje skonsolidowane od nieskonsolidowanych (i od wszystkich innych typów reżimów politycznych)" (Higley, Pakulski, 1999, s. 121-122). Wskazana spójność elity ma dwa wymiary: normatywny - podzielanie wartości, ale i ograniczeń, politycznej rywalizacji; interaktywno-behawioralny, „obejmujący kanały, mechanizmy i sieci, dzięki którym osoby (i grupy) należące do elity uzyskują dostęp do centrów decyzyjnych" (Higley, Pakulski, 1999, s. 122). W dodatku w systemie demokracji skonsolidowanej struktura elity władzy musi być inkluzywna (a nie ekskluzywna), zapewniając stały dopływ do elity najlepszych jednostek wywodzących się z niższych warstw społecznych kosztem tych członków ekipy rządzącej, którzy się po prostu nie sprawdzili. Dlatego też jednym z ważniejszych postulatów dla prowadzenia badań empirycznych jest kwestia cyrkulacji elity. W przypadku systemu demokracji skonsolidowanej cyrkulacja elity charakteryzuje się „otwartością elity i negocjowaną sukcesją" (Higley, Pakulski, 1999, s. 132). Wreszcie istotnym elementem integracji elity jest interakcja jej członków. W ujęciu twórców omawianego paradygmatu stabilna demokracja obejmuje bowiem cały szereg kręgów elity, zjednoczonych jednak w jednym, centralnym kręgu. „Podstawową cechą struktury w każdym kraju jest duży, zróżnicowany, ale mocno zintegrowany krąg centralny, sam zmniejszający się do jądra ciasno powiązanych ze sobą jednostek, z których każda pozostaje w bliskim kontakcie z kilkoma setkami innych członków elity - zarówno w kręgu centralnym, jak i poza nim” (Higley, Hoffmann-Lange, Kadushin, Moore, 1991, s. 45). Struktura ta, zdaniem cytowanych autorów, przypomina lejek.

W ujęciu twórców neofunkcjonalnego paradygmatu elitystycznego pozostałe typy systemów demokratycznych stanowią już „mniejsze zło” (lub czasem i większe), gdyż nie spełniają wszystkich warunków właściwego funkcjonowania ustroju demokracji przedstawicielskiej. „Tam, gdzie występują instytucje proceduralnej demokracji oraz masowe w nich uczestnictwo, ale gdzie brak jest rzeczywistego konsensusu elit odnośnie do demokratycznego porządku w polityce, a poszczególne frakcje elity nie mają do siebie zaufania i wystarczających wzajemnych kontaktów - możemy mówić o demokracji nieskonsolidowanej. 
Zazwyczaj jest ona następstwem nagłego załamania (lub obalenia) reżimu autorytarnego" (Burton, Gunther, Higley, 1995, s. 17). Autorzy omawianego paradygmatu cytują w tym miejscu dwa przykłady takiego systemu: Republika Weimarska w Niemczech (lata 1919-1933) oraz II Republika w Hiszpanii (lata 1931-1933). Jak więc widać, model demokracji nieskonsolidowanej nie tylko wywodzi się z autorytaryzmu, ale i do niego z powrotem prowadzi (lub wręcz do totalitaryzmu). Wprawdzie plusem systemu demokracji nieskonsolidowanej jest możliwość powszechnego udziału społeczeństwa w procedurach demokratycznych, lecz brak porozumienia między elitami powoduje niestabilność i kruchość tego modelu. W pewnym sensie odwrotnością owego modelu jest tzw. stabilna demokracja ograniczona (stable limited democracy). Tak zwana, gdyż w Polsce słowo „ograniczona” kojarzy się jednak inaczej niż ograniczenie do pewnych osób czy spraw - jak w angielskim słowie limited. „Tam, gdzie elity podzielają demokratyczny konsens i są strukturalnie zintegrowane, ale ze względu na restrykcje wyborcze oddolne uczestnictwo polityczne ograniczone jest do grup lepiej usytuowanych [...], możemy mówić o stabilnej demokracji ograniczonej" (Burton, Gunther, Higley, 1995, s. 17). Autorzy omawianego paradygmatu wskazują w tym miejscu na przykłady dwóch państw europejskich z wieku XIX (Wielka Brytania i Szwecja). Proces dochodzenia do powszechnego prawa wyborczego był bardzo długi i wiódł poprzez stopniowe obniżanie cenzusu majątkowego, a wreszcie przyznanie prawa głosu również paniom.

„Możemy wymienić także czwartą, nieco marginalną kategorię - pseudodemokrację. W niektórych systemach odbywają się wybory, które przywódcy tych systemów określają jako demokratyczne, ale żadna z dwóch wymienionych cech demokracji skonsolidowanej nie istnieje w znaczącym zakresie. Typowy przykład to reżimy jednopartyjne" (Burton, Gunther, Higley, 1995, s. 17). W przypadku systemów monopartyjnych oczywiście istnieje tylko jedna elita władzy (ewentualnie tworzy się potem kontrelita), a więc trudno w ogóle mówić o porozumieniu między elitami. Procedury wyborcze stanowią jedynie zasłonę ukrywającą nieskrępowaną władzę jednej, jedynej elity. Podobnie występowały kłopoty (delikatnie to ujmując) z przestrzeganiem praw i wolności obywatelskich, a nawet praw człowieka. To tak jak w czasach Polski Ludowej na pytanie, czy istnieje wolność słowa, odpowiadano (rzecz jasna w swoim gronie): „Oczywiście tak, gorzej tylko z wolnością po słowie”. Autorzy omawianego paradygmatu piszą tutaj o tzw. monarchiach prezydenckich w Afryce, na Bliskim Wschodzie czy w Azji. Obecnie do tej listy dodać można również niektóre państwa Ameryki Łacińskiej, jak Wenezuela czy Nikaragua. „Niewątpliwie jedynie przez grzeczność nie wspomniano w tym miejscu o systemie realnego socjalizmu w Europie Środkowo-Wschodniej, funkcjonującym po II wojnie światowej, a przed »jesienią ludów« lat 1989-1990" (Żyromski, 2007). 


\section{Podsumowanie}

Niewątpliwą zasługą twórców neofunkcjonalnego paradygmatu elitystycznego jest powrót pojęcia (a zatem też teorii elity) do głównego nurtu zainteresowań teoretycznych nauk społecznych - szczególnie politologii i socjologii. Jednocześnie autorzy i propagatorzy omawianego paradygmatu starają się wyraźnie odróżnić od „klasycznych elitystów” (Gaetano Mosca, Vilfredo Pareto, Robert Michels) poprzez podkreślanie roli kontrelity i wskazywanie na znaczenie ciągłego nacisku mas społecznych na elitę aktualnie sprawującą władzę. Wydaje się jednak, że różnice między klasyczną myślą elitystyczną a neofunkcjonalnym paradygmatem elitystycznym są nadmiernie eksponowane. „Wewnętrzne działania, zobowiązania i funkcjonowanie elit określają podstawowe rozróżnienia między systemami politycznymi i gospodarczymi. Zakres wzajemnego zaufania i kooperacji między elitami jest kluczowy dla porozumień konstytucyjnych (i innych instytucjonalnych), dla politycznej i ekonomicznej stabilności bądź niestabilności oraz dla demokratycznych lub autorytarnych praktyk politycznych. W szczególności 'jedność w różnorodności' elity jest warunkiem sine qua non mocnego demokratycznego ustroju politycznego i efektywnej gospodarki rynkowej” (Higley, Lengyel, 2000, s. 1). Oczywiście wszystkie elity (a zwłaszcza te najważniejsze) funkcjonujące w danym państwie muszą przestrzegać reguł demokratycznej rywalizacji i gry politycznej. Jest to właśnie (przedstawiony powyżej) idealny model systemu demokracji skonsolidowanej. Klasyczna myśl elitystyczna narodziła się pod koniec wieku XIX w dużej mierze jako reakcja na marksizm. I również ta tradycja jest obecnie kontynuowana przez autorów neofunkcjonalnego paradygmatu elitystycznego. „Teoria elity, przeciwnie do marksizmu, podkreśla autonomiczną rolę polityki (raczej niż własności) jako ważnego ogniwa pomiędzy władzą polityczną a organizacją biurokratyczną" (Higley, Pakulski, 2000, s. 230).

W wydanym w roku 2018 podręczniku elit politycznych John Higley podkreśla instytucjonalny aspekt władzy elity: „Obecność lub brak stabilnych instytucji politycznych stanowi jeden $\mathrm{z}$ najważniejszych czynników różnicujących w obrębie systemów politycznych, które można wyjaśnić na podstawie różnic w zachowaniu elit politycznych" (Higley, 2018, s. 315). W innym szkicu zawartym w tej samej pracy Higley wskazuje, że same elity są zarazem zróżnicowane, jak i ustratyfikowane: „Elity mogą zostać zdefiniowane jako jednostki i małe (stosunkowo spójne i stabilne) grupy posiadające dużą władzę decyzyjną" (Higley, 2018, s. 27). W ten sposób twórca neofunkcjonalnego paradygmatu elitystycznego wpisuje się w tradycję nie tylko instytucjonalnego, ale i decyzyjnego definiowania elity. Ujęcie decyzyjne pojawiło się już zresztą cztery lata wcześniej w określeniu „elit jako głównych decydentów w potężnych organizacjach (publicznych i prywatnych) na poziomie narodowym czy ponadnarodowym" (Best, Higley, 2014, s. 1). 
Podkreślanie znaczenia aspektu decyzyjnego w określaniu elity implikuje jednocześnie (mniejszy lub większy) poziom niezależności i autonomii członków elity. „We współczesnym społeczeństwie elity są skrępowane przez zasady i praktyki prawno-konstytucyjne. Niemniej zwykle mają wystarczającą autonomię, aby interpretować prawo, modyfikować zasady i kierować potrzebami społecznymi w sposób, który zabezpieczy ich interesy. Elity dokonują tego, wykorzystując potężne siły państwa i mass mediów" (Higley, 2018, s. 25). Wprawdzie dla ochrony własnych interesów elity posiłkują się najczęściej technikami perswazyjnymi, zawsze jednak pozostaje możliwość użycia siły czy innych środków przymusu. A to przecież wszystko w ramach współczesnych państw demokratycznych, opierających się na systemie skonsolidowanej demokracji.

Wreszcie autorzy neofunkcjonalnego paradygmatu elitystycznego odnieśli się również do innych modeli teoretycznych, opisujących strukturę, funkcje i miejsce elit we współczesnym państwie i społeczeństwie. Wskazano na cztery takie modele, co ciekawe rozpoczynając od własnego:

1) „Model elity konsensualnie zintegrowanej. Występuje inkluzywna sieć formalnych i nieformalnych powiązań, przyjaźni, wywierania wpływu między osobami zajmującymi kierownicze pozycje we wszystkich głównych grupach elitarnych (np. biznes, związki zawodowe, polityka, rząd, mass media, dobrowolne stowarzyszenia, elity akademickie itd.). [...] Żadna pojedyncza grupa elitarna nie dominuje w sieci powiązań. Przeciwnie, często występuje interakcja między wszystkimi grupami elitarnymi [...] oraz łatwy dostęp do najważniejszych decydentów" (Higley, Moore, 1981, s. 584).

2) Model elity pluralistycznej, wyróżniony chociażby przez Roberta Dahla, posiada wiele cech poprzedniego modelu. „Podobnie jak w modelu elity konsensualnie zintegrowanej, liderzy wszystkich głównych sektorów, organizacji i grup interesu są obecni w całej sieci interakcji. Tutaj także nie dominuje żadna pojedyncza grupa elitarna. Jednak integracja między grupami elitarnymi nie jest wyraźnie scentralizowana w 'wewnętrznym kręgu’ czy w 'jądrze’ grupy” (Higley, Moore, 1981, s. 584). $\mathrm{W}$ porównaniu $\mathrm{z}$ poprzednim modelem elity rzadsze są tu wzajemne kontakty członków elity, a co za tym idzie - większa jest specjalizacja i autonomia poszczególnych sektorów elity.

3) Model elity władzy, stworzony przez Ch.W. Millsa, wskazuje na ,istnienie klarownej hierarchii i wpływu między grupami elitarnymi, gdzie na szczycie ulokowany jest biznes, politycy, a czasem także wojskowi. $\mathrm{W}$ związku z tym sieć interakcji między głównymi grupami elitarnymi nie jest tak inkluzywna, jak określa to model elity konsensualnie zintegrowanej czy model elity pluralistycznej" (Higley, Moore, 1981, s. 584). 
Natomiast w modelu elity władzy istotna jest wspólnota celów członków elity, ich podobne pochodzenie społeczne (czy losy edukacyjne). Biznes, polityka i wojsko tworzą trzy kręgi elity władzy, a członkowie elity dość swobodnie przemieszczają się między tymi kręgami - nie opuszczając jednak poziomu elity.

4) Model klasy rządzącej wiąże się z kolei z osobą i dorobkiem G. Williama Domhoffa. W tym modelu „zupełnie wyjątkowo występuje inkluzywność czy struktura interakcji elity [...]. Jednak najbardziej prawdopodobne ukształtowanie zostało z grubsza opisane przez model elity władzy. Najważniejsze różnice między tymi dwoma modelami powstają bardziej na poziomie interpretacji niż opisu" (Higley, Moore, 1981, s. 585).

Jan Pakulski, wywodzący się z Polski emerytowany profesor Uniwersytetu w Hobart na Tasmanii (także autor szeregu artykułów w ramach omawianego paradygmatu), poświęcił kilka lat temu osobny artykuł dorobkowi Johna Higleya jako twórcy neofunkcjonalnego paradygmatu elitystycznego (Pakulski, 2012, s. 9-20). Wskazuje przede wszystkim na interdyscyplinarny charakter badań, które „przekraczają granice socjologii, historii i politologii - lokując się w najlepszej tradycji klasycznej teorii społecznej” (Pakulski, 2012, s. 9). Istotne jest szczególnie odnowienie „paradygmatu elitystycznego” ('elite paradigm') przy koncentracji na ogólnopaństwowym poziomie elity (top national power-holders)" (Pakulski, 2012, s. 9). Jednocześnie kontynuując podejście klasycznych twórców teorii elity, to właśnie członkowie elity uważani są za najważniejszych aktorów społecznych, a zwłaszcza za osoby stymulujące zmiany społeczno-polityczne. Natomiast istotnym novum w koncepcji (paradygmacie) Higleya i jego współpracowników jest zwrócenie uwagi na „relacje pomiędzy najważniejszymi cechami elit na szczeblu ogólnopaństwowym, takimi jak integracja i konsensus, a naturą reżimu politycznego (demokratycznego lub nie)" (Pakulski, 2012, s. 9). Mamy do czynienia z bardzo istotną koncepcją teoretyczną, wpisującą się zarówno w zakres teorii polityki (zwłaszcza na poziomie makro), jak i teorii społecznej, badań nad historią społeczną czy analizy politologicznej (osadzonej głęboko w teorii). Pakulski podkreśla także znaczenie i możliwość zastosowania neofunkcjonalnego paradygmatu elitystycznego do analizy procesów społeczno-politycznych zachodzących w państwach, gdzie dokonuje się istotna zmiana systemowa (transformacja). W związku $\mathrm{z}$ tym wiele publikacji napisanych przez twórców i propagatorów omawianego paradygmatu podejmuje kwestię przemian w państwach Ameryki Łacińskiej czy Europy Środkowo-Wschodniej (ich prezentacja wykraczałaby jednak poza ramy i objętość niniejszego szkicu). „Publikacje Higleya łączą refleksję teoretyczną - inspirowaną głównie przez europejskich klasyków teorii elity - z badaniami empirycznymi, w które jest zaangażowany już od pół wieku” (Pakulski, 2012, s. 10). Opinia ta może zostać 
wyrażona również wobec innych protagonistów omawianego paradygmatu (np. M. Burton, M. Dogan, G.L. Field, R. Gunther, J. Pakulski) - może z wyjątkiem tak dużego przedziału czasowego.

Oczywiście w literaturze przedmiotu wyraża się wiele wątpliwości w stosunku do neofunkcjonalnego paradygmatu elitystycznego. Przykładowo wskazywanie na ciągły nacisk mas społecznych (czy inaczej nie-elit) na grupy wchodzące w skład elity społecznej odbywa się na poziomie deklaracji, a nie konkretnych badań empirycznych. Uwaga autorów omawianego paradygmatu skupia się prawie wyłącznie na elitach - i to elitach szczebla ogólnopaństwowego (czy ogólnonarodowego). Z drugiej strony trudno zaprzeczyć, że postawy, działania czy wzajemne relacje między członkami elity mają bardzo istotny (a niekiedy wręcz decydujący) wpływ zarówno na losy przedstawicieli niższych warstw społecznych, jak i nawet na charakter systemu politycznego, jaki rozwija się w danym państwie. Neofunkcjonalny paradygmat elitystyczny jest więc zarówno ważną propozycją teoretyczną, jak i użytecznym narzędziem badania współczesnych reżimów politycznych - zwłaszcza tych, które znajdują się w procesie transformacji (np. przejścia od systemu monocentrycznego do ustroju demokracji skonsolidowanej i gospodarki rynkowej).

\section{Literatura}

Best, H., Higley, J. (2014). „Introduction”. W: H. Best, J. Higley (eds.). Political Elites in the Transatlantic Crisis. New York: Palgrave Macmillan.

Burton, M., Gunther, R., Higley, J. (1992). „Introduction: Elite Transformations and Democratic Regimes". W: J. Higley, R. Gunther (eds.). Elites and Democratic Consolidation in Latin America and Southern Europe. Cambridge: Cambridge University Press.

Burton, M., Gunther, R., Higley, J. (1995). „Elity a rozwój demokracji”. W: J. Szczupaczyński (wybór). Władza i społeczeństwo. Antologia tekstów z zakresu socjologii polityki. Warszawa: Scholar.

Burton, M.G., Higley, J. (1987). „Elite settlements”. American Sociological Review, 52(3), s. 295-307.

Burton, M., Higley, J. (1998). „Political Crises and Elite Settlements”. W: M. Dogan, J. Higley (eds.). Elites, Crises, and the Origins of Regimes. Lanham, MD: Rowman \& Littlefield Publishers Inc.

Dahl, R. (1971). Polyarchy: Participation and Opposition. New Haven: Yale University Press.

Field, G.L., Higley, J. (1980). Elitism. London: Routledge \& Kegan Paul.

Fitzpatrick, S. (2017). Rewolucja rosyjska, przeł. J. Bożek. Warszawa: Wydawnictwo Krytyki Politycznej. 
Higley, J. (2010). „Elite Theory and Elites”. W: K.T. Leicht, J.C. Jenkins (eds.). Handbook of Politics: State and Society in Global Perspective. Handbook of Sociology and Social Research. New York: Springer Science + Business Media, LLC.

Higley, J. (2018). „Continuities and Discontinuities in Elite Theory”. W: H. Best, J. Higley (eds.). The Palgrave Handbook of Political Elites. New York: Palgrave.

Higley, J. (2018). „Political Elites in the West”. W: H. Best, J. Higley (eds.). The Palgrave Handbook of Political Elites. New York: Palgrave.

Higley, J., Burton, M.G. (1989). „The Elite Variable in Democratic Transitions and Breakdowns”. American Sociological Review, 54(1), s. 17-32.

Higley, J., Burton, M. (2006). Elite Foundations of Liberal Democracy. Lanham, MD: Rowman \& Littlefield Publishers Inc.

Higley, J., Deacon, D., Smart, J. (1979). Elites in Australia. London: Routledge \& Kegan Paul. Higley, J., Field, G.L., Grøholt, K. (1976). Elite Structure and Ideology: A Theory with Applications to Norway. Oslo-New York: Columbia University Press.

Higley, J., Hoffmann-Lange, U., Kadushin, Ch., Moore, G. (1991). „Elite Integration in Stable Democracies: A Reconsideration”. European Sociological Review, 7(1), s. 35-53. Higley, J., Lengyel, G. (2000). „Introduction: Elite Configurations after State Socialism”. W: J. Higley, G. Lengyel (eds.). Elites after State Socialism: Theories and Analysis. Lanham, MD: Rowman \& Littlefield Publishers Inc.

Higley, J., Moore, G. (1981). „Elite Integration in the U.S. and Australia”. American Political Science Review, 75, s. 581-597.

Higley, J., Pakulski, J. (1995). „Elite Transformation in Central and Eastern Europe”. Australian Journal of Political Science, 30, s. 415-434.

Higley, J., Pakulski, J. (1999). „Elites in the Study of Consolidated Democracy”. W: A. Jasińska-Kania, M.I. Kohn, K.M. Słomczyński (eds.). Power and Social Structure: Essays in Honor of Włodzimierz Wesołowski. Warszawa: Wydawnictwa Uniwersytetu Warszawskiego.

Higley, J., Pakulski, J. (2000). „Epilogue. Elite Theory versus Marxism. The Twentieth Century's Verdict”. W: J. Higley, G. Lengyel (eds.). Elites after State Socialism: Theories and Analysis. Lanham, MD: Rowman \& Littlefield Publishers Inc.

Higley, J., Pakulski, J., Wesołowski, W. (1998). „Introduction: Elite Change and Democratic Regimes in Eastern Europe”. W: J. Higley, J. Pakulski, W. Wesołowski (eds.). Postcommunist Elites and Democracy in Eastern Europe. Basingstoke: Macmillan Press Ltd.

Kahlberg, J., Higley, J., Pakulski, J. (1998). „Elites, Institutions and Democratisation in Russia and Eastern Europe”. W: G. Gill (ed.). Elites and Leadership in Russian Politics: Selected Papers from the Fifth World Congress of Central and East European Studies, Warsaw 1995. Basingstoke: Macmillan Press.

Miński, R. (2016). Aktualność myśli Roberta Michelsa. Warszawa: Uniwersytet SWPS i Wydawnictwo Scholar. 
Pakulski, J. (2012). „John Higley's Work on Elite Foundations of Social Theory and Politics”. Historical Social Research, 37(1), s. 9-20.

Sartori, G. (1987). The Theory of Democracy Revisited I: The Contemporary Debate. Chattam, NJ: Chatham House Publishers.

Wasilewski, J. (1990). Społeczne procesy rekrutacji regionalnej elity władzy. WrocławWarszawa-Kraków-Gdańsk-Łódź: Ossolineum.

Żyromski, M. (1995). The Elite in the Lower Danube Provinces of the Roman Empire. Mosina: Alpim Book.

Żyromski, M. (1996). Gaetano Mosca. Twórca socjologicznej teorii elity. Poznań: Wydawnictwo Naukowe UAM.

Żyromski, M. (1998). „Kilka uwag o procesie dochodzenia do demokracji w świecie współczesnym”. Zeszyty WSNHiD, 1, s. 121-128.

Żyromski, M. (2006). „Przydatność tzw. neofunkcjonalnego paradygmatu elitystycznego do analizy wybranych systemów społeczno-politycznych”. Przegląd Politologicz$n y, \mathrm{XI}(4)$, s. 7-14.

Żyromski, M. (2007). Teorie elity a systemy polityczne. Poznań: Wydawnictwo Naukowe UAM.

Żyromski, M. (2008). „Założenia tzw. neofunkcjonalnego paradygmatu elitystycznego jako przykład ewolucji teorii elit”. W: M. Mikołajczyk, M. Śliwa (red.). Kontynuacje i nowatorstwo w świecie współczesnych idei. Kraków: Wydawnictwo Naukowe Akademii Pedagogicznej.

Żyromski, M. (2009). „Porozumienia 'Okrągłego Stołu’ a tzw. neofunkcjonalny paradygmat elitystyczny. W: W. Polak, J. Kufel, M. Chechłowska, P. Nowakowski, D. Chrul (red.). Okragły Stót - dwadzieścia lat później. Toruń: Wydawnictwo Adam Marszałek. Żyromski, M. (2012). The Three "Founding Fathers" of Elites's Theory: Mosca, Pareto and Michels. Poznan: Faculty of Political Science and Journalism Adam Mickiewicz University. Żyromski, M. (2016). „The Transition Process in Poland and Hungary and the Neofunctional Elitist Paradigm”. W: M. Rachwał, B. Pająk-Patkowska (red.). Hungary and Poland in Times of Political Transition: Selected Issues. Poznań: Wydawnictwo Naukowe WNPiD.

\section{Streszczenie}

Tak zwany neofunkcjonalny paradygmat elitystyczny to najnowsza (choć rozwijana już od połowy lat 70. XX wieku) wersja teorii elity. Niemniej teoria elity wywodzi się jeszcze z końca XIX wieku - powstała w głębokim konflikcie $\mathrm{z}$ funkcjonowaniem systemu demokracji przedstawicielskiej. Włoscy „ojcowie założyciele” teorii elity (szczególnie Gaetano Mosca i Vilfredo Pareto) przeciwstawiali się pomysłom wprowadzenia powszechnego prawa wyborczego, a także wykorzystali nastroje głębokiego rozczarowania związane z procesem zjednoczenia Włoch (Risorgimento). Już w roku 1928 polski uczony Czesław Znamierowski zaprezentował pewne warunki zgodności między występowaniem elity a funkcjonowaniem ustroju demokratycznego. 
W ujęciu najważniejszych przedstawicieli tzw. neofunkcjonalnego paradygmatu elitystycznego (zwłaszcza Johna Higleya) pewne cechy elity stanowią jedno z kryteriów klasyfikacji demokratycznych systemów politycznych. Nawet współcześnie najczęściej występują na świecie elity podzielone (czy inaczej: sfragmentaryzowane). W takiej sytuacji elity funkcjonujące $\mathrm{w}$ danym państwie nie potrafią dojść do porozumienia (czy kompromisu) nawet w odniesieniu do podstawowych kwestii politycznych. Niewątpliwie lepiej, kiedy elity (przynajmniej najważniejsze elity w danym państwie) potrafią dojść ze sobą do porozumienia. Takie porozumienie może opierać się na podstawie wspólnie wyznawanej ideologii (tzw. elity ideologicznie zintegrowane), tak jak w ustrojach o charakterze totalitarnym. $\mathrm{Z}$ drugiej strony o wiele lepiej, kiedy podstawą integracji między elitami są wspólnie podzielane wartości demokratyczne (jak w modelu elit konsensualnie zintegrowanych). Już 30 lat temu w Polsce podczas negocjacji Okrągłego Stołu takie właśnie porozumienie zostało osiągnięte - w procesie porozumienia między elitami (elite settlements).

Słowa kluczowe: neofunkcjonalny paradygmat elitystyczny, elity podzielone, porozumienie między elitami, elity ideologicznie zintegrowane, elity konsensualnie zintegrowane 